UDC 81'373.45

DOI: $10.17223 / 24109266 / 9 / 6$

\title{
PORTUGUESE MILITARY DISCOURSE IN BRAZIL
}

\author{
L.V. Meshkov, A.A. Ignatov \\ National Research Tomsk State University (Tomsk, Russian Federation) \\ E-mail: ifrycarp@mail.ru; ignatov_aa@sibmail.com
}

\begin{abstract}
This article considers Portuguese military discourse in Brazil, and also the material, which is essential while teaching Portuguese to military interpreters. The history of the replenishment of an all-Portuguese militarytechnical lexicon is presented here. The most important periods of formation of Portuguese military discourse in Portuguese-speaking countries is considered. The influence of loanwords on all-Portuguese military-technical lexicon is described.
\end{abstract}

Keywords: military discourse; military interpreter; Portuguese; militarytechnical lexicon; loanword.

\section{Introduction}

The formation of the Brazilian version of the Portuguese language as well as national versions of other languages was primarily due to social factors - geographical and further political division of a single society. Since Brazil has been a colony of Portugal for a long time being isolated, there is no doubt that foreign policy factors influenced the formation of a military discourse since military-technical vocabulary is an integral part of the vocabulary of Portuguese. This vocabulary originated as the result of a long historical process, as a complex language formation, the development of which was determined, on the one hand, by the laws of development of military affairs and history of the Portuguesespeaking society, on the other hand - by patterns and conditions of the development of this language.

\section{Terminology}

Complex consideration of military terminology presupposes the solution of a range of interconnected tasks, such as the identification of sources of origin of military terminological units (TU) in Portuguese; the description of the development of an all-Portuguese military-technical lexicon (MTL) and its basis at the beginning of the process of the differentiation in the language of its national versions; the establishment of characteristic methods of military-terminological nomination at certain stages of the history of Portuguese and its national versions; the typology of semantic processes that took place in diachrony at the stage of acquir- 
ing military terminology in European Portuguese (PE) and Brazilian Portuguese $(\mathrm{PB})$ of nationally specific traits.

The following terms and terminological units that are part of the allPortuguese military-terminological lexicon dates to the initial period of the formation of Portuguese military terminology (up to the $19^{\text {th }}$ century):

- names related to the organization and construction of the armed forces, for example: forças, armas, corpo; cavalaria, artilharia, infantaria, esquadra, esquadrão, armadas, frota;

- describing servicemen according to their professional status and professional characteristics, for example: almirante, capitão do mar, marechal general, general em chefe, alferes, tenente, soldado, marinheiro, grumete;

- names of types of combat operations, methods of conducting these operations, tactical maneuvers, combat formation of troops, for example: defesa, ataque, defender, atacar, abrir (fazer) brecha, sitiar, emboscada, praça de armas, posição, retaguarda, vanguarda, flanquear;

- names of weapons and their nomenclature, etc., for example: espingarda, boca de fogo, canhão, tubo, bala, fecho, carregar, carregamento pela boca, reparo, disparar.

All these terms were formed, primarily, under the influence of external factors; that is, they are connected with the necessity of generating and fixing in the language new designations associated with military affairs. The analyzed material enables us to make a conclusion that in the initial period of the formation of Portuguese military terminology $\left(15-19^{\text {th }}\right.$ centuries $)$, the development of a relatively integral and organized system of means for the expression of military concepts was started, and the creation of a basic lexicon of military terminology of Portuguese began.

The most important extralinguistic factor, which directly influenced the replenishment of the all-Portuguese military-technical lexicon, was the rapid scientific and military-technical progress of the $19-20^{\text {th }}$ centuries.

Firstly, it caused significant changes in the technology of production of conventional weapons systems, for example, artillery and small arms in developed countries. This caused the necessity of translating all this kind of information in another language, for example, English or Russian. As a result, military interpreters appeared since military cooperation was established between the USSR and Great Britain, Spain and Portugal [1,2].

Secondly, it contributed to the emergence of fundamentally new types of armament and combat equipment: submarines, automatic small arms, aviation, armored vehicles, etc. The majority of the new systems were adopted for service by modern armies at that time practically simultaneously. This could also be due to allied relations between groups of countries in peace- 
time or their participation, such as, for example, Portugal and Brazil, in world wars on the side of one of the opposing forces.

Thirdly, military and technical progress has led not only to improving the means of armed struggles, but also to qualitative changes in the structure of the armed forces: the emergence of new armed services and arms, and also changes in military specialties.

Therefore, during the period under consideration, the most intensive process of replenishment of the all-Portuguese military-technical lexicon was observed in the following areas:

- names of armament systems and combat materiel: espingarda de repetição, espingarda automática, metralhadora, cano raiado, cartucho metálico, carro de combate, avião de caça, bombardeiro, submarino, couraçado, encouraçado, torpedeiro;

- names related to the structure of the armed forces, armed services and arms, for example: Força Aérea, artilharia antiaérea, Corpo de paraquedistas, Cavalaria Blindada, Transmissões, Esquadra s de Submarinos, Batalhão Mecanizado;

- designations of servicemen according to their professional characteristics, for example: piloto-aviador, piloto-navegador, radista, telegrafista, paraquedista.

All these terms designate new military and technical concepts related to the development of armament systems, for example: extração do invólucro vasio, depósito girante do revólver, escorva de composição fulminante.

Models of a higher stage of production were not found. This is obvious because the synchrony of the terminological combination of the third stage of production is often represented by neologisms and usually belong to the sphere of functioning or, according to Golovin's definition, "speech terms" [3].

Speaking about the loaning of terms as a way of replenishing the Portuguese military-technical lexicon, we will concentrate only on some aspects of this problem that are important for our study, because there are too many factors, which can influence loaning as, for example military occupation or the adoption of a new religion [4].

The results of the conducted analysis of military terminology prove that the national element has always played a dominant role in its composition. According to our calculations, loanwords in the general core of military-technical lexicon amount to $20-25 \%$ of the total number of TU. We suppose that these terms can be considered to be loanwords only from the point of view of their origin. In the modern period they are recognized by native speakers as "national" lexical units and entered the military sublanguage so organically, that, according to R.A. Budagova, they "remain foreign language elements only in the sense of etymology" [5]. 
The question of the nature and conditions of the course of the semantic changes in assimilated terms, the dependence of these processes on the time of loaning (synchrony or diachrony), in our opinion, has not yet been finally determined and apparently needs further research $[6,7]$. It is more important for the purposes of our research that loanwords have become one of the reasons for the emergence of terminological synonyms in the general core of the military-technical lexicon. For example: boca de fogo $(\mathrm{P})$ - peça de artilharia; força $(\mathrm{P})$ - tropa; míssil $(\mathrm{P})$ - foguete; fuzil - espingarda; tripulação (P) - equipagem [8].

Finishing our brief consideration of loanwords as a way of enriching the Portuguese military-technical lexicon, we note that having gained national independence, Brazil rather quickly reoriented to military cooperation with English-speaking countries. In Portugal, this change was completed only by the middle of the 20th century. This gives reason to consider that in the Brazilian military-technical lexicon English-origin loanwords (assimilated and non-assimilated) played a far greater role than in the Portuguese military-technical lexicon.

\section{Conclusion}

In the article, Portuguese military discourse in Brazil was described, as well as the way how foreign policy relations influenced greatly the development of political military discourse throughout the development of Brazil in different periods of time. Also, the most significant periods of replenishment of the all-Portuguese military-technical lexicon were considered. Examples were also provided of the areas, which were replenished by new words and consideration was given to the process of formation of Portuguese military language. The characteristics of the allPortuguese military-technical lexicon were introduced.

\section{References}

1. Shevchenko, M.A., Mitchell, P.J. (2013). Educating military interpreters in civilian higher education institutions. Language and Culture. 1 (21). pp. 125-131.

2. Mitchell, P.J., Shevchenko, M.A. (2014). Teaching military linguists: The experience of the British Army. Vestnik of Moscow University. Series 19: Linguistics and intercultural communication. 3. pp. 141-148.

3. Mitchell, P.J., Akhtambaev, R.P., Ignatov, A.A. (2014). The influence of military contacts on French loanwords in the English language. Language and Culture. 2 (26). pp. 69-73.

4. (1979). Termin i slovo. Mezhvuz. sb. Gork. obl. un-t im. M.N. Lobachevskogo. Gorkij: Gork. gos. un-t.

5. Budagov, R.A. (1989). Tolkoviye slovari v natsionalnoy kulture narodov. Moscow: Izd-vo Mosk. un-ta.

6. Belogub, A.L. (1975). Sotsiolingvisticheskiye predposilki migratsii terminologicheskoy leksiki. (Na materiale nem. otraslevoy podsistemy stankostroyeniya). Avtoref. dis. ... kand. filol. nauk. Kiev. 
7. Semenets, O.E. (2005). Sotsialniy kontekst i yazikovoye: Territorialnaya i sotsialnaya differentsiatsiya angliyskogo yazika v razvivayushihsya stranah. Kiev: Visha shkola.

8. Fonseca, V. (1985). O português entre as Línguas do Mundo. Coimbra: Livraria Almedina.

Resived 02.05.2017

Information about the authors:

Meshkov Lev - student, Department of English Philology, Faculty of Foreign Languages, National Research Tomsk State University (Tomsk, Russian Federation). E-mail: ifrycarp@mail.ru

Ignatov Artyom - first lieutenant, instructor, Institute of Military Education, National Research Tomsk State University (Tomsk, Russian Federation). E-mail: ignatov_aa@sibmail.com 